\title{
Inhibiton of tumor-derived prostaglandin-e2 prevents the induction of human myeloid-derived suppressor cells (MDSCs) and rescues anti-tumor immunity
}

\author{
Yumeng Mao ${ }^{1 *}$, Dhifaf Sarhan ${ }^{1}$, Isabel Poschke ${ }^{2}$, Andreas Lundqvist ${ }^{1}$, Rolf Kiessling ${ }^{1}$ \\ From Society for Immunotherapy of Cancer 29th Annual Meeting \\ National Harbor, MD, USA. 6-9 November 2014
}

\section{Background}

Cancer progression is associated with a severe impairment of anti-tumor immune responses. The accumulation of peripheral blood CD14+HLA-DRlo/- monocytic MDSCs has been identified as a prognostic factor in advanced stage melanoma patients. These cells suppress $\mathrm{T}$ cell functions ex vivo and reversely correlate with the frequencies of antigen-specific $\mathrm{T}$ cells in patients. However, the precise mechanistic basis underlying this effect is unclear, particularly with regard to how MDSCs are induced and how they could limit functions of NK cells in cancer patients.

\section{Methods}

The effects of tumor-derived factors in inducing phenotypic and functional alternations on healthy human monocytes or CD34+ hematopoietic stem cells (HSCs) were analyzed in vitro, by co-culturing monocytes with earlypassage tumor cells or addition of tumor-conditioned medium, respectively. Suppression of T or NK cell activity by MDSC-like cells was compared with that of freshly isolated CD14+HLA-DRlow/- monocytic MDSCs (moMDSCs) from patients with melanoma. In addition, to explore the in vivo relevance of targeting PGE2 to reduce MDSC expansion, we established a murine model, where tumor cells were disabled from cyclooxygenase-2 (COX-2) production and in vivo NK cytotoxicity was evaluated by live imaging.

\section{Results}

We recently demonstrated that tumor-derived factors promoted monocytes to acquire an MDSC-like phenotype and suppressive functions of $\mathrm{T}$ cells via COX-2/PGE2 pathway (Mao et al. Cancer Res., 2013). Moreover, tumorderived factors resulted in a retention of c-kit+ cells $(\mathrm{p}<0.05)$ and hampered differentiation of CD34+ HSCs to functional myeloid cells. As a result, these cells showed decreased ability to stimulate $\mathrm{T}$ cells to proliferate and produce IFN $\gamma(\mathrm{p}<0.05)$. In patients with melanoma, freshly isolated CD14+HLA-DRlow/- moMDSCs strongly suppressed cytotoxicity $(\mathrm{p}<0.05)$ and production of IFNg ( $\mathrm{p}<0.01$ ) by NK cells, through production of TGF $\beta$ $(\mathrm{p}<0.05)$. In vitro, binding of PGE2 to EP2 or EP4 receptors on monocytes activated the p38MAPK/ERK pathway and resulting in elevated secretion of TGF $\beta(\mathrm{p}<0.05)$ and reduced NK cell cytotoxicity $(\mathrm{p}<0.01)$. Importantly, silencing COX-2 in 4T1 tumor cells reduced the frequency of splenic CD11b+Gr1+ MDSCs ( $<<0.01)$, resulting in concomitant improved in vivo clearance of NK-sensitive YAC-1 target cells $(\mathrm{p}<0.05)$.

\section{Conclusions}

Collectively, our results reveal a direct involvement and molecular machinery of tumor-derived factors, in particular PGE2, in inducing immature phenotype and stimulating suppressive functions from MDSCs. Therefore, combining COX-2 inhibitors with immunotherapy may result to a favorable clinical outcome in patients with cancer.

\section{Authors' details}

${ }^{1}$ Karolinska Institutet, Stockholm, Sweden. ${ }^{2}$ German Cancer Research Center (DKFZ), Heidelberg, Germany.

${ }^{1}$ Karolinska Institutet, Stockholm, Sweden

Full list of author information is available at the end of the article 
Submit your next manuscript to BioMed Central and take full advantage of:

- Convenient online submission

- Thorough peer review

- No space constraints or color figure charges

- Immediate publication on acceptance

- Inclusion in PubMed, CAS, Scopus and Google Scholar

- Research which is freely available for redistribution

Submit your manuscript at www.biomedcentral.com/submit
C Biomed Central 